\title{
Secondary School Students' Text Possession, Attitude to English Language Learning and Home Background as Factors Affecting Their Learning of English Language
}

\author{
Patience I. O. Aika ${ }^{1 *} \quad$ Stella I. Uyi-Osaretin ${ }^{2} \quad$ Rose J. Musa $^{2}$ \\ 1.Department of Curriculum and Instructional Technology, Faculty of Education, University of Benin, PMB \\ 1155, Benin City, Nigeria \\ 2.Department of Curriculum and Instructional Technology, Faculty of Education, University of Benin, PMB \\ 1154, Benin City, Nigeria
}

\begin{abstract}
The English language enjoys a high status in Nigeria. In the school system, English is a compulsory subject from the upper primary school level onwards. However, it has been observed that students perform poorly in the subject. Several reasons have been adduced for this. While previous studies have focused on several learner factors, a few empirical studies exist on students' attitude to learning English Language, students' home background and students' possession of recommended English Language textbooks. Against this background, this study investigated students' text possession, attitude to English Language learning and home background as factors affecting the learning of English Language. The study adopted the descriptive survey research design. The sample comprised 333 senior secondary school students in Benin City. Three research questions were raised. Data were collected using an instrument titled 'Text Possession, Attitude and Home Background Questionnaire' (TPAHQ, $r=.74$ ). Results revealed that students have positive attitudes toward the learning of English Language and an enabling home background for the effective learning of English Language. In addition, students do not possess the recommended English Language textbooks. It is recommended that teachers should use engaging teaching methods to sustain the positive attitudes students have towards learning English Language. Similarly, parents should continue to ensure that their homes are conducive to effective learning. Finally, textbooks should be made available for students.
\end{abstract}

Keywords: Text possession, Attitude to English Language, Home background, English Language learning DOI: $10.7176 / \mathrm{JEP} / 12-24-11$

Publication date: August $31^{\text {st }} 2021$

\section{Introduction}

The English language enjoys a high status in Nigeria. It is the language of formal education, the language of government, business and commerce, the mass media and others. Apart from being the medium of instruction from the upper primary level of education onwards, the language is taught as a compulsory subject in schools. Due to the multi-lingual and multi-cultural nature of the country, English serves as the medium of intra-national and inter-national communication. Urevbu (1984) notes that it is a generally accepted necessity in Nigeria to learn English at some stage.

However, scholars such as Ezeokoli (2002), Oladunjoye (2005), Asokhia (2009), Ojetunde (2010) and Nwigwe and Izuagba (2017) have observed that students perform poorly in English Language examinations such as those conducted by the West African Examinations Council (WAEC) and the National Examinations Council (NECO). Many students find it difficult to secure admission into higher institutions of learning because of their inability to obtain a minimum of a credit pass in English Language in the Secondary School Certificate Examinations (SSCE).

A plethora of reasons exists for the poor state of students' performance in English Language. These reasons range from teacher variables such as poor methodology, teachers' attitude to teaching English Language, teacher qualification and years of teaching experience to school variables such as learning environment and school location. In addition, there are some reasons that are traceable to the learner which forms the focus of this study. They include the learner's possession of relevant textbooks, the learner's home background and the learner's attitude toward learning the English Language.

Textbooks perform a pivotal role in the teaching/learning process. They are perhaps the most widely used teaching resource (Murray and Perez, 2011). Teachers consistently rely on them for delivering content and for assessing what students do and learn (Oakes \& Sanders, 2004; Fitzpatrick \& McConnell, 2009). Textbook serves as a time saver for the teacher as it gives direction to lessons, guides discussions, facilitates the giving of homework and makes teaching easier, better organized and more convenient (Hutch and Torres, 1994). For learners, their access to textbooks ensures that they can with the subjects' content, at school and at home which should aid their academic achievement in the subject (Oakes and Saunders, 2002). In other words, textbooks help learners to organize their learning both in and out of the classroom (Hutch and Torres, 1994). Drawing 
inferences from a number of researches, Frolich and Michealowa (2005) surmise that the textbook is an effective and rather inexpensive means of improving educational achievement and cognitive development.

In most language programmes in an ESL context such as is the case of Nigeria, much of the language input learners receive and the language practice that takes place comes from the recommended textbooks (Noordin \& Samad, 2005). In some situations, the textbook supplements the teacher's instruction. For many English teachers in an ESL setting, textbooks provide the content of what is taught in class as well as the source of assignments given. To extend their language learning beyond classroom time, students depend on the textbooks for homework assignments or personal study. In sum, the textbook serves as a vital resource for ESL teachers and their learners.

In spite of the importance of textbooks in English Language learning, the literature reveals that students do not possess the relevant textbooks. For example, Gbenedio (1996) observes that in a typical English Language class, only a few students possess the recommended textbook. Similarly, other scholars have noted the poor state of students' possession of recommended textbooks. In the case of a related subject -Literature-in-English - it has been observed that only a few students possess the recommended textbooks (Ogunnaike, 2002; Olasele, 2007; Nwaigwe, 2007; Olutoyin, 2010; Igubor, 2011). Thus, there is a need to ascertain if students possess the relevant textbooks for learning English Language.

Moreover, students' performance in English language can also be affected by their home background. Home background of students covers several sub-variables. This study however focuses on parents' educational background, parental involvement in their children's learning and parents' socio-economic status. Research reveals that the home is an important factor in determining the literacy achievement of a learner as the process of becoming literate begins long before a child enters a formal education system (Van Standen \& Howie, 2010). Parents' educational background refers to the highest educational level attained by either parent. The results of several studies indicate that parents with low levels of literacy are less likely to help their children with reading and writing since they feel less confidence in doing so (Williams, Clemens, Oleinikoua, \& Tarvin, 2003; Parsons \& Bynner, 2007). Similarly parents with low levels of literacy are less likely to have children who read for pleasure (Parsons \& Bynner, 2007). These parents are at risk of having children with lower cognitive and language development levels (De Coulon, Meschi \& Vignoles, 2008). Farooq, Chaudhry, Shafiq, \& Berhanu's (2011) study which examined the different factors influencing the academic performance of secondary school students in Pakistan revealed that parental education has an effect on students' academic performance.

Furthermore, parents can have a significant influence on their children's English Language achievement through supporting their learning at home. Epstein (2001) describes three ways that parents can participate in their children's education: School-based participation; home-based participation; and parent-teacher communication. The focus here is on home-based participation. Home-based participation refers to activities that tend to be initiated by parents and occur at home. These activities range from providing for their children's nutrition and health to ensuring that the home conditions are conducive to learn. In addition, it includes learningat-home activities such as reading with children or helping children with homework (Edge, Tao, Riley, \& Khamsi, 2008).

Similarly, Harris and Goodall (2007) argue that parents make the greatest difference to their children's achievement through supporting their learning at home rather than by supporting their activities in the school. Several researches have produced evidence justifying the importance of parental support of their children's learning to their literacy levels and educational achievement (Desforges \& Abouchaar, 2003; Gest, Freeman, Domitrovich \& Welsh, 2004; Flouri \& Buchanan, 2004). Parental support for children's learning is also associated with increased motivation in relation to students' learning. Gonzalez-DeHass, Willems, and Holbein's study (2005) shows that when parents are involved in students learning, students reported increased effort, concentration, attention, interest in and responsibility for learning and higher perceived confidence.

Another home background variable that can affect students' achievement in English Language is parents' socio-economic status (SES). SES has been found to affect language development (Noble, Norman \& Farah, 2005). Van Staden and Howie's (2010) study on factors affecting students' reading performance in South Africa presents strong evidence that socio economic status particularly affects reading achievement. In higher socioeconomic households, average reading scores were higher compared to those households with lower socioeconomic status. Children from higher SES backgrounds stand a better chance of owning books and having greater access to resources such as museums or libraries (Bradley, Corwyn, Pipes McAdoo, \& Garcia Coll, 2001) than students from lower SES. SES has repeatedly been shown to be associated with home literacy environment, which in turn is associated with language learning.

Moreover, attitude is another important factor influencing language performance. Attitudes can be defined as 'a person's enduring favorable or unfavorable evaluations, emotions or action tendencies toward some object or idea' (Boone \& Kurtz, 2015, p.186). Language attitude. Language learners' attitudes towards the language exercises a considerable influence on the language learning process and the learning outcomes (Todor \& Degi, 2016). Researchers such as Csizér (2007), Dörnyei (2009) and Abidin, Pour-Mohammadi and Alzwari (2012) 
argue that attitude constitutes one of the most important sets of variables for predicting learner achievement. When learners have positive attitudes toward the language and its speakers, there is increased motivation for learning which likely results in better learning achievement. Similarly, Lennartsson (2008) avers that students' negative attitude toward a language will serve as an obstacle to learning the language.

Due to the importance of attitude in language learning, several studies have been carried out to ascertain students' attitude towards learning the English Language. For example, Tsuda's (2003) study on Japanese students' attitude towards the learning of English Language revealed that the students held negative attitudes toward the learning of the English Language. Ahmed's (2005) study focused on the attitude of undergraduate English as a Foreign Language (EFL) students' towards English Language learning in Malaysia. The results showed that students' attitude towards English language learning and usage in various domains is extremely positive. Eshghinejad (2016) investigated the attitude of male and female English as a foreign language (EFL) learners of Kashan University toward English language learning in terms of the behavioural, cognitive, and emotional aspects. Results showed a positive attitude toward English learning. Wayar (2017) investigated the gender based attitude of students towards English in northern Nigeria. Findings revealed that students' generally have a positive attitude towards learning the English Language.

\subsection{Statement of the Problem}

Students perform poorly in English Language examinations. Various factors have been identified to explain the situation. Previous researches have focused on the attitudes of learners toward English Language learning. However, few empirical studies on students' attitude to English Language learning exist in the Nigerian context. Similarly, other studies have considered the learner's background in relation to English Language learning. None of such studies seem to have focused simultaneously on students' level of text possession, their parents' educational background and socio-economic status. Against this background, this study investigated secondary school students' text possession, attitude to English Language learning and home background as factors affecting their learning of English Language.

\subsection{Research Questions}

The following research questions were raised to guide the study:

1. Do secondary school students possess the relevant materials necessary for the effective learning of English Language?

2. What is the attitude of secondary school students toward the learning of English Language?

3. What is the state of students' home background as it relates to the learning of English Language?

\section{Methodology}

The descriptive survey research design was adopted for the study. The Population of the study comprises senior secondary school 2 students in public schools in Benin City. The sample for the study comprises of three hundred and thirty three senior secondary school (SS II) students. The sample was selected using the simple random sampling technique. Three (Egor, Oredo and Ikpoba-Okha) out of the five local government areas (LGAs) in Benin City were randomly selected. Thereafter, four schools were randomly selected from each LGA, which brings the total number of schools to twelve. A minimum of twenty-five students were randomly selected from each school.

The instrument for data collection is a questionnaire titled 'Text Possession, Attitude and Home Background Questionnaire' (TPAHQ). The questionnaire consists of thirty items in two parts. Section A seeks the respondents' demographic information while Section B contains items designed to measure students' text possession, attitude toward learning English Language and home background.

The instrument was designed by the researchers. In order to determine the reliability of the instruments, it was administered on thirty students of similar status as those used in the study. However, this sample was excluded from the study sample. Data collected were analyzed using Cronbach's alpha and it yielded a reliability co-efficient of .74.

The questionnaire was administered personally by the researchers and collection was on-the-spot. Two interpretative norms were applied to analyze the data collected viz:

When the mean score is greater or equal to 2.51 , then there is an agreement by the subjects.

If the measure of consistency is greater or equal to .75 , then the subjects have agreed with the item.

These two criteria were used in combination to determine when there is an agreement. The belief is that this condition is more stringent than using either of them. Consistency value was computed using the formula $\mathrm{C}=1 \frac{s 2}{w 2}$

Where $\mathrm{S}=$ variance

$\mathrm{W}=$ highest weight 


\section{Results}

The findings of the study are presented in the order of the research questions raised.

\subsection{Research Question One}

Do secondary school students possess the relevant materials necessary for the effective learning of English Language?

Table 1: Students' Possession of Relevant Materials for Learning English Language

\begin{tabular}{|l|l|l|l|l|l|l|}
\hline Item & $\mathrm{N}$ & Minimum & Maximum & Mean & Std. Deviation & Acceptable level of agreement \\
\hline Relevant material & 333 & .00 & 3.00 & .79 & .745 & 1.51 \\
\hline
\end{tabular}

Table 1 reveals that the mean score for relevant materials is .79 which is lesser than the acceptable level of agreement of 1.51. Therefore, it can be concluded that the students do not possess the relevant materials necessary for the effective teaching of English Language.

\subsection{Research Question Two}

What is the attitude of secondary school students toward the learning of English Language?

Table 2: Students' Attitude toward the Learning of English Language

\begin{tabular}{|l|l|l|l|l|l|l|}
\hline Item & $\mathrm{N}$ & Minimum & Maximum & Mean & Std. Deviation & Acceptable level of agreement \\
\hline Attitude & 333 & 5.00 & 18.00 & 8.47 & 1.67 & 6.1 \\
\hline
\end{tabular}

From Table 2, it can be seen that the mean score of 8.47 is higher than the acceptable level of agreement of 6.1. This result implies that students have positive attitude toward learning English Language.

\subsection{Research Question 3}

What is the state of students' home background as it relates to the learning of English Language?

Table 3: Home Background and Students' Learning of English Language

\begin{tabular}{|l|l|l|l|l|l|l|}
\hline Item & $\mathrm{N}$ & Minimum & Maximum & Mean & Std. Deviation & Acceptable level of agreement \\
\hline Home background & 333 & 00 & 4.00 & 3.04 & 1.03 & 2.1 \\
\hline
\end{tabular}

Result from Table 3 shows that the mean score is 3.04. The score is higher than the acceptable agreement level of 2.1. Therefore, it can be concluded that students possess the enabling home background necessary for the effective learning of English Language.

\section{Discussion of Results}

Result to research question one study revealed that students do not possess the relevant textbooks necessary for learning English Language. This result aligns with the findings of previous researches on students' level of textbook possession which showed that students do not possess the recommended textbooks necessary for effective learning (Gbenedio, 1996; Ogunnaike, 2002; Olasele, 2007; Nwaigwe, 2207; Olutoyin, 2010; Igubor, 2011).The finding also indicates that the problem of students' non-possession of recommended textbooks is a persistent one that has to be addressed. This problem could be a major cause of students' poor performance in English Language since much of the English language content students are expected to learn in a second language situation like that of Nigeria, is embedded in the textbook (Noordin \& Samad, 2005).

Furthermore, the result of the analysis to research question two revealed that students have a positive attitude towards learning English Language. This result is in consonance previous studies which showed that students generally have positive attitude towards learning English Language (Ahmed, 2005; Eshghinejad, 2016; Wayar, 2017). However, the result is in contrast to that of Tsuda (2003) which revealed that students have negative attitudes toward the learning of English Language. A factor that could account for students' positive attitude towards English Language is the status of English. English enjoys an enviable status in Nigeria coupled with the fact that students cannot progress in their educational journey without doing well in English Language examinations. In addition, the result is an indication that if students possess the recommended textbooks for learning English Language, they might do well in the subject as positive attitudes towards learning a language are highly correlated with better learning achievement (Abidin et al., 2012).

Finally, result of research question three showed that students possess the enabling home background necessary for the effective learning of English Language. This result could also account for students' positive attitude towards English Language as the home background is supportive of English Language learning. As Gonzalez et al.'s (2005) study shows, parental involvement in students' learning leads to increased motivation for learning.

\section{Conclusion}

Learner factors can exercise a powerful influence on students' achievement. From the findings of this study, it can be concluded that students' do not possess the recommended textbooks, they have positive attitudes towards English Language learning and they possess the enabling environment for the effective learning of English 
Language. Based on the findings of the study, it is recommended that students' positive attitudes toward the learning of English Language learning should be sustained by teachers through teaching that engages the learners in the learning process.

In addition, parents should continue to ensure that their children have a conducive home environment for learning all the school subjects. Finally, the recommended English Language textbooks should be made available to learners who cannot afford to own them. Government could subsidize these textbooks or make them free for indigent students. Similarly, teachers should help students see the need of studying the recommended textbooks so as to improve upon their performance in English Language.

\section{References}

Abidin, M. J. Z., Pour-Mohammadi, M., \& Alzwari, H. (2012), 'EFL Students' Attitudes towards Learning English Language: The case of Libyan Secondary School Students', Asian Social Science, 8(2), 119-134.

Ahmed, S. (2005), 'Attitudes toward English Language Learning among EFL Learners at UMSKAL', Journal of Education and Practice, 6(18), 6-16.

Asokhia, M.O. (2009), 'Improvisation/Teaching Aids: Aids to Effective Teaching of English'. International Journal of Education Science, 1(2), 79-85.

Boone, L.E., \& Kurtz, D.L. (2015), 'Contemporary Marketing'. USA: Cengage Learning.

Bradley, R. H., Corwyn, R. F., McAdoo, H. P., \& García Coll, C. (2001), 'The Home Environments of Children in the United States Part I: Variations by Age, Ethnicity, and Poverty Status', Child Development, 72(6), 1844-67.

Csizér, Kata. (2007). 'Anyelvtanulási motiváció vizsgálata.Angolul és németül tanuló diákok motivációs beállítódása a nyelvválasztás tükrében [Examining Language Learning Motivation. English and German Language Learners' Motivational Attitudes towards Language Choice].Új Pedagógiai Szemle, '57(6), 5468.

Desforges, C. and Abouchaar, A. (2003), 'The impact of parental involvement, parental support and family education on pupil achievement and adjustment: a literature review', London: Department for Education and Skills.

Dörnyei, Z. (2009), Motivational Self-System. In E. Ushioda \& Z. Dörnyei (Eds.), 'Motivation, Language Identity and the L2 Self' (pp. 9-42), Bristol: Multilingual Matters.

Edge, K., Tao, S., Riley, K., \& Khamsi, K. (2008). 'Teacher Quality and Parental Participation: An Exploratory Review of Research and Resources Related to Influencing Student Outcomes', London: University of London Centre for Leadership in Learning.

Epstein, J. (2001), 'School, Family and Community Partnerships: Preparing Educators and Improving Schools', Boulder, CO: Westview Press.

Eshghinejad, S. (2016), 'EFL Students' Attitudes toward Learning English Language: The Case Study of Kashan University Students', Cogent Education, 3, 1-13.

Ezeokoli, F. O. (2002), What West African Examinations (WAEC) Senior School Certificate Examination Literature-In-English Tests. In A. Mansaray, \& I.O. Osokoya, (Eds.), 'Curriculum Development at the Turn of the Century: The Nigerian Experience', Ibadan: Department of Teacher Education

Farooq, M.S., Chaudhry, A.H., Shafiq, M. \& Berhanu, G. (2011), 'Factors Affecting Students' Quality of Academic Performance: A case of Secondary School Level', Journal of Quality and Technology Management, 7(2), 1-14.

Fitzpatrick, L., \& McConnell, C. (2009),' Student Reading Strategies and Textbook Use: An Inquiry into Economics and Accounting Courses', Research in Higher Education Journal, 3, 1-10.

Flouri, E., \& Buchanan, A. (2004),' Early Fathers and Mother's Involvement and Child's Later Educational Outcomes,' British Journal of Educational Psychology 74(2), 141-153.

Frolich, M., and Michealowa, K. (2005). 'Peer Effects and Textbooks in Primary Education: Evidence from Francophone Sub-Saharan Africa' (IZA Discussion Paper No. 1519). Retrieved from http://ftp.iza.org/dp1519.pdf

Gbenedio, U.B. (1996), 'Teaching and Learning English As a Second Language', Lagos: New Era Publication.

Gest, S.D., Freeman, N.R., Domitrovich, C. E. \& Welsh, J.A. (2004), 'Shared Book Reading and Children's Language Comprehension Skills: The Moderating Role off Parental Discipline Practices', Early Childhood Research Quarterly 19(2), 319-336.

Gonzalez-DeHass, A.R., Willems, P.P., \& Holbein, M.F.D. (2005), Examining the Relationship between Parental Involvement and Student Motivation', Educational Psychology Review 17(2), 99-123.

Harris, A. \& Goodall, J. (2007), 'Engaging Parents in Raising Achievement: Do Parents Know They Matter?' London: Department for Children, Schools and Families. Retrieved from http://dera.ioe.ac.uk/6639/1/DCSF-RW004

Hutchinson, T., \& Torres, E. (1994),'The Textbook as an Agent of Change. English Language Teaching Journal 
48(4), 315-328.

Igubor, P. (2011), 'Text Possession, Teacher's Instructional Organization and Methods of Teaching Prose Literature in ESL Classrooms in Ibadan'. M.Ed. Thesis, University of Ibadan.

Lennartsson, F. (2008). Students' Motivation and Attitudes towards Learning a Second Language: British and Swedish Students' Points Of View. Retrieved from http://www.divaportal.org/smash/get/diva2:206523/fulltext01.pdf

Murray, M., \& Perez, J. (2011), 'E-Textbooks Are Coming: Are We Ready?' Issues in Informing Science and Information Technology (IISIT) 8, 49-60. Retrieved from http://iisit.org/Vol8/IISITv8p049060Murray307.pdf

Noble K. G., Norman M. F., \& Farah M. J. (2005), 'Neurocognitive Correlates Of Socioeconomic Status in Kindergarten Children', Developmental Science 8(1), 74-87.

Noordin, N., \& Samad, A. A. (2005), 'Examining the Importance of EST and ESL Textbooks and Materials: Objectives, Content and Form', English for Specific Purposes World 1(9). Retrieved from http://espworld.tp.com/articles_9/textbooks.htm.ESPworld169vol42005

Nwaigwe, C. P. (2007), 'Text Possession and Preparation for the Senior School Certificate Literature in English Examination in Some Schools in Ibadan, Oyo State'. Unpublished B.Ed Project, University of Ibadan.

Nwigwe, N.V., \& Izuagba, A.C. (2017), 'An Analysis of the Grammatical Errors of Igbo-Speaking Graduates' Written English: Implications for Teaching', International Journal of Language, Literature and Gender Studies (LALIGENS) 6(2), 65-78.

Oakes, J. \& Saunders, M. (2004), 'Education's Most Basic Tools: Access to Textbooks and Instructional

Materials in California's Public School', Teachers College Record 106(10), 1967-1988.

Oakes, J., \& Saunders, M. (2002), 'Access to Textbooks, Instructional Materials, Equipment, And Technology: Inadequacy and Inequality in California's Public Schools', Los Angeles: University of California.

Ogunnaike, J. (2002), 'Challenges of the Teaching and Learning Of Literature In Nigerian Secondary Schools' In A, Lawal, I. Isiugo-Abanihe \& N. I.Ohia. (Eds), Perspectives on Applied Linguistics in Language and Literature (pp. 334-344). Ibadan: Sterling-Horden Publishers.

Ojetunde, C.F. (2010), 'The Usage of English Adverbials by Students in Selected Tertiary Institutions in South Western Nigeria'. Unpublished Ph.D. Thesis, Obafemi Awolowo University, Ile-Ife, Nigeria.

Oladunjoye, O. (2005), 'Secondary School Student's Perception of the English Language as a Qualifying Subject of Entrance into Nigerian Universities'. In A. Dada, A. Abimbade and C O.O. Kolawole (Eds). Issues in Language, communication and education (pp.139-146). Ibadan: Counstellation Books.

Olasele, O.G.F. (2007), 'What Teachers and Students do to Prepare for the Senior Secondary School Certificate Examination In Literature in English in Some Schools In Lagos'. B. Ed Project, University of Ibadan.

Olutoyin, B.J. (2010), 'Towards the Enhancement of Literacy Acquisition in Literature Classrooms Discourse in Nigerian Universities', The Indian Review of World Literature in English 6(11). Retrieved from http://www.worldlitonline.net/towards.the.pdf.

Parsons, S. \& Bynner, J. (2007), 'Illuminating Disadvantage: Profiling the Experiences of Adults with Entry Level Literacy or Numeracy over the Life Course'. National Research and Development Centre for Adult Literacy and Numeracy (Research report). Retrieved from www.nrdc.org.uk/publications details.asp? ID $=125$

Todor, E., \& Degi, Z. (2016), 'Language Attitudes, Language Learning Experiences and Individual Strategies. What Does It Offer and What Does It Lack?' ACTA Universitatis Sapientiae, Philologica 8(2), 123-137.

Tsuda, S. (2003), 'Attitudes towards English Language Learning in Higher Education in Japan (2). Raising Awareness of the Notion of Global English. Intercultural Communication Studies 12(3), 61-75.

Urevbu, A.O. (1984). English Language and the Mother Tongue Dilemma in Nigeria: A Critical Assessment of the New National Policy on Education. International Journal of Educational Development 4(1), 23-30.

Van Staden, S \& Howie, S. (2010) 'South African Teacher Profiles and Emerging Teacher Factors: A Picture Painted by PIRLS 2006', Reading and Writing 1(1), 47-60.

Wayar, B. (2017), 'Gender-Based Attitudes of Students towards Learning English Language in Northern Nigeria'. International Journal of Innovative Language, Literature \& Art Studies 5(3), 7-17.

Williams, J., Clemens, S., Oleinikova, K., \& Tarvin, T. (2003), 'The Skills for Life Survey: A National Needs and Impact Survey Of Literacy, Numeracy And ICT Skills'. DFES Research Brief 490. London: Department for Education and Skills 